\title{
В.Г. Басарева
}

\section{ПРОБЛЕМЫ СИБИРСКОГО ФЕДЕРАЛЬНОГО ОКРУГА В КОНТЕКСТЕ ЗАДАЧ ВОССТАНОВЛЕНИЯ ЭКОНОМИЧЕСКОГО РОСТА}

\author{
V.G. Basareva \\ PROBLEMS OF THE SIBERIAN FEDERAL DISTRICT \\ IN THE CONTEXT OF RECOVERY OF ECONOMIC GROWTH.
}

Рассматривается задача восстановления экономического роста для условий Сибири, где в предыдущий экономический период были допущены определенные отставания в социально-экономическом развитии от среднероссийского уровня. Анализируются статистические показатели 2014-2015 гг., которые, по мнению экспертов, отражают динамику драйверов экономического роста. Показано, что регионы СФО ухудшили свое положение. Падение потребительского рынка и инвестиций в основной капитал превышают показатели по России в целом. Субъекты РФ, входящие в округ, демонстрируют высокую неравномерность в развитии, что предопределяет особенности регионального и муниципального управления социально-экономическим развитием округа. Отраслевая специализация регионов не обеспечивает потенциала повышения доходов населения. Государственная политика регулирования и поддержки малого предпринимательства не нацелена на улучшение пространственной структуры малого предпринимательства, что приводит при падении доходов населения к закрытию предприятий, сокращению рабочих мест, еще большему сокращению доходов населения округа. На основании анализа динамики объемов государственного долга и дефицита консолидированных бюджетов субъектов РФ делается вывод, что у регионов СФО нет достаточных бюджетных ресурсов для поддержания потенциала экономического роста. Формулируются рекомендации для снижения воздействия сложившихся отрицательных тенденций в разных сферах. Обосновывается необходимость разработки новой редакции Стратегии СФО с включением новых задач, связанных с проектным подходом ускорения экономического роста, который обеспечит концентрацию финансовых, управленческих, административных ресурсов на решении наиболее важных конкретных задач в экономике и социальной сфере СФО с выходом на ощутимые, реальные результаты.

СУБЪЕКТЫ ФЕДЕРАЦИИ; ФАКТОРЫ ЭКОНОМИЧЕСКОГО РОСТА; ПОТРЕБИТЕЛЬСКИЙ РЫНОК; ИНВЕСТИЦИИ; ОТРАСЛЕВАЯ СПЕЦИАЛИЗАЦИЯ; КОНСОЛИДИРОВАННЫЕ БЮДЖЕТЫ; ОБЪЕМ ГОСУДАРСТВЕННОГО ДОЛГА.

The task of restoring economic growth is considered in the article for the conditions of Siberia, which experienced a certain decline in its social and economic development in the previous economic period compared to the national average. We have analyzed the statistics of 2014-2015, which, according to experts, reflect the dynamics of the drivers of economic growth. It is shown that the situation has deteriorated in the regions of the Siberian Federal District (SFD). The decline in the consumer market and investments in fixed assets exceed the figures for Russia as a whole. The subjects of the Federation, members of the district exhibit high nonuniformity in the development. The sectoral specialization of regions does not provide the potential to increase incomes. State policy of regulation and support of small business is not aimed at improving the spatial structure of small businesses, which will can lead to falling household incomes, plant closures, job cuts, and further reduction of the regional income. Based on the analysis of the dynamics of public debt and deficit volumes of consolidated budgets of subjects of the Russian Federation, we can conclude that the SFD subjects do not have sufficient budgetary resources to maintain growth potential. We have formulated recommendations for reducing the impact of the existing negative trends in different areas. We have proved it is necessary to develop a new version of the district's strategy that would include new tasks associated with the project approach to accelerating economic growth, which will provide a concentration of financial, managerial and administrative resources on the most important specific problems in the economy and social sphere of the SFD, yielding tangible, measurable results.

SUBJECTS OF THE FEDERATION; FACTORS OF ECONOMIC GROWTH; CONSUMER MARKET; INVESTMENTS; INDUSTRY SPECIALIZATION; SMALL BUSINESS; CONSOLIDATED BUDGETS; AMOUNT OF PUBLIC DEBT. 
Введение. Выступая на пленарном заседании Петербургского международного экономического форума в июне 2016 г. Президент России В.В. Путин дал оценку и поставил ряд стратегических и текущих задач социальноэкономического развития страны. Он подчеркнул, что сохраняются структурные проблемы, накопленные в глобальной экономике, исчерпаны прежние источники роста: «Перезапустить рост пока не удается». Возобновление роста - задача ближайшей перспективы. Озвучена задача выйти на темпы роста экономики не менее чем $4 \%$ в год [2].

Восстановление экономического роста с необходимостью требует коррекции набора мер и мероприятий, обеспечивающих достижение ранее обозначенных рубежей в развитии страны. Эксперты сходятся во мнении, что экономика страны располагает необходимым потенциалом для выполнения поставленных целей. Академик В.В. Ивантер считает, что необходимо «выполнить две главные задачи: во-первых, простимулировать потребительский спрос, во-вторых, простимулировать инвестиции в реальный сектор» [6, с. 3].

Важным фактором реализации потенциала роста является разработка и внедрение мер, которые могут способствовать использованию имеющихся возможностей для стабилизации условий функционирования малого бизнеса и восстановления доверия предпринимателей к государству $[9,18,19]$.

Еще одно условие, отмеченное экспертами, - поддержание и восстановление устойчивого (равновесного) состояния экономики. «Формирование текущих (в виде бюджетного дефицита или повышенной инфляции) или долгосрочных (в виде избыточного накопления долга) дисбалансов снижает стимулы для сбережения и инвестиций, несет риски финансового кризиса, замедляя тем самым экономический рост - соответственно необходимо не допускать таких дисбалансов» [4].

Перечисленные факторы обеспечения роста характерны для экономики страны в целом. Однако учитывая, что в современных теориях регионального управления регион исследуется как многофункциональная и многоаспектная система и одна из ее парадигм рассматривает регион как «Квазигосударство» [3], используем те же подходы для оценки потенциала СФО в процессе восстановления экономического роста.
Выбор СФО в качестве объекта анализа потенциала роста не случаен. Для Сибири задача восстановления экономического роста сопряжена с рядом трудностей объективного характера. Как отмечал академик В.В. Кулешов, Сибирский федеральный округ по показателям социального развития отстает от России в целом. Поставлена задача: основные показатели социально-экономического развития Сибири к 2020 г. должны соответствовать среднероссийскому уровню, следовательно, темпы их прироста должны опережать средние по РФ [7, с. 7]. Для выполнения поставленной задачи округ должен обладать более значительным потенциалом роста, чем страна в целом.

Постановка проблемы. По уровню социально-экономического развития в СФО выделяются три группы регионов. Первая группа - регионы с относительно высокой плотностью населения, относительно сбалансированной аграрной и промышленной экономикой, сравнительно высоким уровнем развития инфраструктуры (Алтайский край, Новосибирская, Омская и Томская области). В этих регионах сосредоточен основной научно-образовательный и аграрный потенциал, обрабатывающий и перерабатывающий сектора промышленности. Вторая группа промышленные регионы, характеризующиеся высоким уровнем развития перерабатывающей промышленности и ресурсных отраслей (Иркутская и Кемеровская области, Красноярский край, Республика Хакасия). Третья группа - регионы с относительно низкой плотностью населения и сравнительно низким уровнем социально-экономического развития, к которым можно отнести Республику Алтай, Республику Бурятия, Республику Тыва и Забайкальский край [11].

Отмеченные различия предопределяют особенности регионального и муниципального управления социально-экономическим развитием округа, а также принципы и меры государственной региональной политики, направленной на обеспечение устойчивого повышения уровня и качества жизни населения [13].

Цель исследования - с учетом особенностей СФО рассмотреть проблемы, стоящие перед регионами, входящими в состав округа, путем анализа тенденций, характерных для факторов, влияющих на экономический рост в период кризисных явлений в экономике 2014- 
2015 гг., и предложить направления их решения. При этом круг проблем как перечень сложных теоретических и практических вопросов, требующих разрешения, с учетом мнения экспертов о драйверах экономического роста сводится к следующему перечислению:

- будет ли потребительский спрос в СФО стимулом для восстановления экономического роста?

- обеспечит ли рынок инвестиций СФО восстановление экономического роста?

- созданы ли необходимые условия для обеспечения стимулирующего влияния малого предпринимательства на потенциал экономического роста в СФО?

- есть ли у регионов СФО бюджетные ресурсы для поддержания потенциала экономического роста?

Методика исследования. В процессе исследования проблемы восстановления регионального экономического роста используются методы логического, статистического анализа. В соответствии с поставленной задачей проводится диагностика динамики основных показателей факторов экономического роста в период кризисных явлений 2014-2015 гг. К таким показателям СФО относятся:

- реальные доходы населения;

- оборот розничной торговли;

- объем платных услуг населению;

- инвестиции в основной капитал;
- уровень развития малого предпринимательства;

- средства господдержки, выделяемые Минэкономразвития на поддержку малого предпринимательства регионам СФО;

- исполнение консолидированных бюджетов субъектов РФ в 2015 г., входящих в СФО;

- объемы государственного долга субъектов РФ СФО.

Новизна подхода состоит в комплексном рассмотрении в одном периоде времени и применительно к одному объекту СФО информации организаций и ведомств, координация деятельности которых представляется недостаточной, рассматривается раздельно, что и приводит к низкой обоснованности прогнозируемых тенденций.

\section{Результаты исследования.}

СФО: динамика потребительского рынка и инвестиции. В табл. 1 представлены индексы изменения показателей, характеризующих состояние потребительского рынка федеральных округов и инвестиций в основной капитал. СФО - единственный округ, демонстрирующий по всем показателям отрицательную динамику за рассматриваемый период. Реальные доходы населения, оборот розничной торговли, объем платных услуг - показатели, характеризующие потребительский рынок, сокращаются в СФО. Это сокращение превышает значения в целом по России.

Т а блица 1

Индексы роста (снижения) показателей социально-экономического развития федеральных округов к предыдущему году", \%

\begin{tabular}{|l|c|c|c|c|c|c|c|c|}
\hline \multirow{2}{*}{$\begin{array}{c}\text { Федеральный } \\
\text { округ }\end{array}$} & \multicolumn{2}{|c|}{$\begin{array}{c}\text { Реальные доходы } \\
\text { населения }\end{array}$} & \multicolumn{2}{c|}{$\begin{array}{c}\text { Оборот розничной } \\
\text { торговли }\end{array}$} & \multicolumn{2}{c|}{$\begin{array}{c}\text { Объем платных } \\
\text { услуг населению }\end{array}$} & \multicolumn{2}{|c|}{\begin{tabular}{c} 
Инвестиции основной капитал \\
\cline { 2 - 9 }
\end{tabular}} \\
\cline { 2 - 9 } Россия & 2014 & 2015 & 2014 & 2015 & 2014 & 2015 & 2014 & 2015 \\
ЦФО & 99,5 & 95,3 & 102,7 & 90,0 & 101,3 & 98,0 & 97,3 & 91,6 \\
СЗФО & 101,4 & 94,0 & 102,6 & 89,7 & 99,2 & 98,4 & 92,4 & 90,9 \\
ЮФО & 103,3 & 96,5 & 1043 & 92,4 & 104,6 & 103,9 & 83,2 & 82,1 \\
СКФО & 103,6 & 95,5 & 104,3 & 95,5 & 103,9 & 100,7 & 109,1 & 93,3 \\
ПФО & 102,1 & 95,1 & 103,4 & 87,2 & 102,3 & 96,5 & 98,9 & 92,5 \\
УФО & 98,4 & 93,8 & 99,0 & 88,1 & 102,5 & 97,2 & 101,3 & 95,7 \\
СФО & 98,2 & 95,5 & 98,6 & 85,4 & 99,1 & 96,6 & 98,3 & 83,3 \\
ДВФО & 102,8 & 100,1 & 105,0 & 99,1 & 101,5 & 100,0 & 94,8 & 96,6 \\
\hline
\end{tabular}

* Из-за отсутствия некоторых данных не представлена информация по Крымскому федеральному округу.

И с т о ч н и к : [14]. 


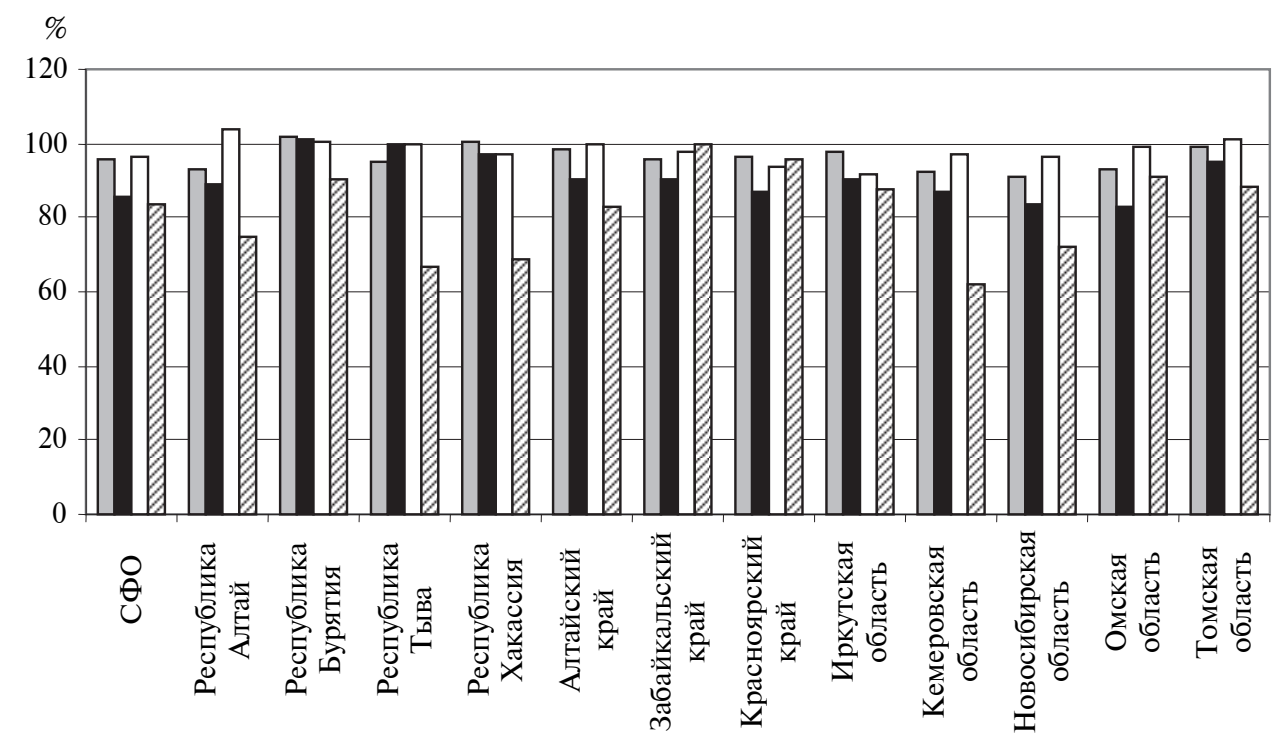

Рис. 1. Индексы роста(снижения) показателей социально-экономического развития субъектов СФО в 2015 г. в \% к 2014 г.

$(\square)$ - реальные доходы населения; $(\square)$ - оборот розничной торговли;

$(\square)$ - объем платных услуг населению; $(\nabla)$ - инвестиции в основной капитал.

Источник: [14].

Тенденции 2014-2015 гг. на потребительском рынке сохранились в январе-апреле 2016 г. Реальные денежные доходы населения СФО сократились - 93,4\% по отношению к январю-апрелю 2015 г., что превышает этот показатель в целом по России $-95,2 \%$. Оборот розничной торговли в январе-мае 2016 г. составил $93 \%$, по сравнению с январем-маем 2015 г.; по России в целом $94,3 \%$. Объем платных услуг населению в январе-мае 2016 г. по отношению к январю-маю 2015 г. составил по России - 99,2 \%. В СФО - 97,1\% [15].

Одновременно фиксируется падение инвестиций в основной капитал, причем в 2015 г., по сравнению с 2014 г., инвестиции сократились почти на $17 \%$ при $8,4 \%$ по России в целом. Другие федеральные округа (за исключением ЮФО) демонстрируют по показателю инвестиции в основной капитал более «сдержанные» негативные тенденции.

Данные по показателям субъектов СФО демонстрируют значительную дифференциацию социально-экономического положения регионов в 2015 г. (рис. 1). Лидером по сокращению реальных доходов населения стала Новосибирская область - 91 \% по отношению к 2014 г.

Отмеченное сокращение повлияло на потребительский рынок области: оборот роз- ничной торговли $-83,5 \%$ по отношению к 2014 г., объем платных услуг - 96,3\%. Инвестиции в основной капитал сократились до $72 \%$ по отношению к 2014 г.

Из всех субъектов СФО только Республика Бурятия сохранила на прежнем уровне состояние потребительского рынка за счет незначительного роста реальных доходов населения - $102 \%$ по отношению к 2014 г.

Рынок инвестиций СФО демонстрирует существенное сокращение по регионам. Лидер падения - Кемеровская область, где инвестиции в основной капитал в 2015 г. сократились на $38 \%$ по отношению к предыдущему году; в Тыве - на $33 \%$, Хакасии - на $31 \%$.

Отметим, что негативные тенденции на потребительском рынке и в сфере инвестиций сложились при достаточно благополучных тенденциях в промышленности и сельском хозяйстве. Так, если в целом по России индекс промышленного производства составил $96,6 \%$, то в СФО - 100,2\%. Индекс производства продукции сельского хозяйства в России $-103 \%$, в СФО - $102 \%$.

Республика Алтай отчиталась за рост промышленного производства - $126 \%$. Только четыре региона (Республика Хакасия, Забайкальский край, Красноярский край, Томская область) снизили объемы промышленного 
производства, но это снижение не превышало $2 \%$. Схожая картина по индексу производства продукции сельского хозяйства: Алтайский край увеличил этот показатель на 7,5 \%, пять регионов показали падение (Республики Бурятия, Тыва, Хакасия, Забайкальский край, Иркутская область) от 1,5 до $7 \%$.

Приведенные данные подтверждают общую картину текущего кризиса. «Надо понимать, что это в меньшей степени промышленный кризис. Он не про заводы, хотя и есть проблемные. Промышленности это коснулось частично» [5].

Особенность кризиса, которая проявляется и в СФО, - это кризис потребления и инвестиций. Стратегия поддержания потребительского спроса становится центральной при решении задач восстановления экономического роста в силу специфики отраслевой специализации регионов округа. Именно поэтому необходимо отслеживать тенденции, которые могут возникнуть в отраслях специализации регионов, непосредственно связанных с поведением потребителей.

Отраслевая структура определяется, в том числе, количеством занятых в тех или иных отраслях экономики. В сельском хозяйстве и промышленности (добыча полезных ископаемых, обрабатывающие производства, производство и распределение электроэнергии, газа и воды) трудятся 28,5 \% занятых в экономике округа. В образовании, здравоохранении и предоставлении социальных услуг в округе занято $16,5 \%$. В этой сфере можно ожидать снижение реальных располагаемых доходов работающих из-за отмены в 2016 г. индексации заработной платы бюджетников. В оптовой и розничной торговле, ремонте автотранспортных средств, мотоциклов, бытовых изделий, предметов личного пользования и в операциях с недвижимостью - в сферах деятельности, зависящих от потребительского спроса и поведения потребителей, занято $25,2 \%$. Эти отрасли в значительной мере состоят из предприятий малого бизнеса.

Влияет ли отраслевая специализация регионов России, определяемая структурой занятости, на среднедушевые доходы населения, а следовательно, и на потребительский спрос? Нами сформирована модель множественной регрессии, отражающая влияние pe- гиональных факторов на среднедушевые доходы населения региона, и проведены расчеты на панельных данных 2009-2012 гг., которые содержали 328 наблюдений [17].

Расчеты показали, что регионы с высокой долей занятых в промышленности и сельском хозяйстве имеют более низкие среднедушевые доходы населения. Высокая доля занятых в строительстве характерна для регионов с более высокими среднедушевыми доходами населения. При этом достаточно высокая и значимая корреляция фиксировалась в период 2009-2012 гг. между среднедушевыми доходами населения и численностью занятых в малом бизнесе $(+0,4)$, что позволяет предположить: уровень развития малого бизнеса в регионе положительно и значимо влияет на факторы, формирующие потребительский спрос. Те отрасли, которые традиционно связаны с крупными фирмами, прежде всего, промышленность, на текущий момент не обладают потенциалом, который приводит к росту среднедушевых доходов населения регионов. Это добавочная аргументация в пользу развития и всесторонней поддержки малого бизнеса, который такой потенциал имеет.

О мерах по развитию малого бизнеса в СФО. Малый бизнес потенциально способен играть роль катализатора регионального роста и инноваций, обеспечивая тем самым ориентацию российских регионов на новые приоритеты и источники развития. Малые предприятия лучше, чем крупные компании, приспособлены удовлетворять разнообразные потребности населения и сегментировать рынки, способствуя повышению качества жизни населения и среды его обитания. Успех в поставленных задачах восстановления экономического роста в России во многом зависит от активного участия в этих процессах малого бизнеса.

В СФО по данным на конец 2014 г. было расположено 302 тыс. малых предприятий, относящихся к юридическим лицам, или 14,3\% всех малых предприятий России. На 1000 населения, проживающего на территории округа, приходится 15,6 малых предприятий, что выше среднего значения по России. Среднесписочная численность занятых на малых предприятиях без учета внешних совместителей составляет 1362,9 тыс. чел., или 14,8 \% 
всех занятых в округе, что ниже доли занятых на малых предприятия по России - $15,9 \%$. СФО отстает по доли занятых в малом бизнесе от округов-лидеров - Центрального и Северо-Западного Федеральных округов.

Отраслевая структура малых предприятий СФО близка к общероссийской структуре. Обрабатывающие производства МП составляют чуть больше $9 \%$, в России и в СФО в этом виде деятельности заняты порядка $14 \%$ среднесписочной численности занятых в малом бизнесе. Высока доля малых предприятий, относящихся к оптовой и розничной торговле, ремонту автотранспортных средств, бытовых изделий и предметов личного пользования более $39 \%$ всех предприятий и в РФ и в СФО.

Отметим, что несмотря на потенциальную значимость и роль малого бизнеса как важнейшего сектора региональной экономики, государственная политика регулирования и поддержки малого предпринимательства не нацелена на улучшение пространственной структуры малого предпринимательства. Такой вывод напрашивается при сравнении основных показателей развития малых предприятий субъектов РФ, входящих в СФО (табл. 2), и данных об объеме субсидий, полученных регионами СФО из федерального бюджета на поддержку малого и среднего предпринимательства (табл. 3).

Данные табл. 2 демонстрируют сложившийся рейтинг регионов, входящих в СФО, по развитию малого предпринимательства. Безусловное лидерство занимает здесь Новосибирская область. Высокий уровень предпринимательской активности позволяет области удерживать первое место по количеству малых предприятий в Сибирском федеральном округе и восьмое в России. В этом регионе действовало около 63 тыс. малых предприятий - юридических лиц. Плотность МП на 1000 чел. - 23 ед. Самая высокая доля занятых (без внешних исполнителей) на малых предприятиях в среднесписочной численности занятого населения области $-19,7 \%$.

Второе место в этом рейтинге занимает Красноярский край, где на конец 2013 г. действовало, по данным Росстата, более 52 тыс. малых предприятий, на 1000 жителей этого региона их приходится 18,4. Среднесписочная численность работников малых предприятий Красноярского края составила 213 тыс. чел., или 14,9\% в среднесписочной численности занятых в крае. Оборот малых предприятий этого региона в 2013 г. составил 392,9 млрд р.

Таблица 2

Основные показатели развития малых предприятий субъектов РФ СФО в 2013 г.

\begin{tabular}{|l|c|c|c|c|c|c|}
\hline \multicolumn{1}{|c|}{ Субъект РФ } & $\begin{array}{c}\text { Количество } \\
\text { МП, ед. }\end{array}$ & $\begin{array}{c}\text { Плотность } \\
\text { МП }\end{array}$ & $\begin{array}{c}\text { Среднесписочная } \\
\text { численность } \\
\text { работников МП, } \\
\text { тыс. чел. }\end{array}$ & $\begin{array}{c}\text { Доля занятых } \\
\text { МП в средне- } \\
\text { списочной } \\
\text { численности, \% }\end{array}$ & $\begin{array}{c}\text { Оборот } \\
\text { МП, } \\
\text { млрд руб. }\end{array}$ & $\begin{array}{c}\text { Инвестиции } \\
\text { в основной } \\
\text { капитал, } \\
\text { млрд руб. }\end{array}$ \\
\hline СФО & 290066 & 15,0 & 1348,8 & 14,8 & 2635,8 & 87,9 \\
Республика Алтай & 2263 & 10,7 & 10,1 & 11,3 & 10,2 & 1,2 \\
Республика Бурятия & 10995 & 11,3 & 41,3 & 9,9 & 63,2 & 0,7 \\
Республика Тыва & 1560 & 5,0 & 6,1 & 5,9 & 6,7 & 0,6 \\
Республика Хакасия & 6390 & 12,0 & 29,2 & 12,5 & 39,1 & 0,3 \\
Алтайский край & 35596 & 14,9 & 168,3 & 15,7 & 281,1 & 20,7 \\
Забайкальский край & 5604 & 5,1 & 39,9 & 8,2 & 63,5 & 1,0 \\
Красноярский край & 52384 & 18,4 & 213,0 & 14,9 & 392,9 & 11,7 \\
Иркутская область & 28918 & 12,0 & 170,9 & 15,1 & 381,6 & 1,3 \\
Кемеровская область & 33585 & 12,3 & 187,0 & 14,3 & 326,3 & 18,7 \\
Новосибирская область & 62798 & 23,0 & 267,0 & 19,7 & 558,2 & 20,9 \\
Омская область & 29204 & 14,8 & 142,9 & 15,1 & 378,0 & 8,8 \\
Томская область & 20769 & 19,4 & 73,3 & 14,8 & 135,0 & 1,9 \\
\hline
\end{tabular}

И с т о чн и к : [8]. 
Таблица 3

Объем субсидий, полученных регионами СФО из федерального бюджета на поддержку малого и среднего предпринимательства

\begin{tabular}{|l|c|c|c|}
\hline \multirow{2}{*}{ Регион СФО } & \multicolumn{2}{|c|}{ Объект субсидий, тыс. руб. } & Соотношение, \% \\
\cline { 2 - 4 } & 2012 & 2013 & $2013 / 2012$ \\
\hline Сибирский федеральный округ & 3340530,3 & 3202024,1 & 0,96 \\
Республика Алтай & 243531,0 & 35168,8 & 0,14 \\
Республика Бурятия & 424529,9 & 540326,8 & 1,27 \\
Республика Тыва & 49286,0 & 50918,9 & 1,03 \\
Республика Хакасия & 80000,0 & 81626,2 & 1,02 \\
Алтайский край & 318400,0 & 284600,0 & 0,89 \\
Забайкальский край & 200434,0 & 302759,7 & 1,51 \\
Красноярский край & 615663,0 & 438478,7 & 0,71 \\
Иркутская область & 353045,4 & 310872,2 & 0,88 \\
Кемеровская область & 152723,0 & 126574,0 & 0,83 \\
Новосибирская область & 430285,0 & 446138,0 & 1,04 \\
Омская область & 284434,0 & 245193,9 & 0,86 \\
Томская область & 188199,0 & 339367,0 & 1,80 \\
\hline
\end{tabular}

Третье место - у Алтайского края. На территории этого региона - более 35 тыс. малых предприятий, где работает почти $16 \%$ среднесписочной численности занятых. Объем инвестиций малых предприятий Алтайского края превысил показатель Красноярского края - 20,7 млрд р.

Республика Тыва по представленным показателям 2013 г. замыкает рейтинг регионов СФО. Плотность МП на 1000 чел. - всего 5 ед. Доля занятых на малых предприятиях не превышает $6 \%$.

Рейтинг регионов по уровню развития малого бизнеса никак не связан с данными об объемах субсидий, полученных регионами СФО из федерального бюджета на поддержку малого и среднего предпринимательства. Почему, например, Республика Алтай фактически была лишена поддержки? Новосибирская область и Красноярский край - лидеры рейтинга, но субсидии в 2013 г. для Красноярского края сократились, Новосибирская область получила увеличение, по сравнению c 2012 г. Общий объем субсидий в 2013 г. снизился в округе, по сравнению с 2012 г., хотя округ отстает от округов-лидеров.

В текущей экономической ситуации негативное воздействие на развитие малого предпринимательства СФО оказывают сокращение реальных доходов населения и дефицит финансовых возможностей, что приводит к закрытию малых предприятий, сокращению ра- бочих мест, дальнейшему сокращению реальных доходов населения, создает определенные трудности в процессе восстановления роста.

Проблемы бюджетной системы в СФО. Есть ли у регионов СФО бюджетные ресурсы для поддержания потенциала экономического роста? Для ответа на этот вопрос представим данные о состоянии консолидированных бюджетов регионов округа. По оперативным данным Федерального казначейства консолидированные бюджеты субъектов РФ, входящих в СФО, исполнены в 2015 г. с дефицитом (табл. 4.). Дефицит СФО составил 78 млрд р. Дефицит консолидированных бюджетов соответствует норме Бюджетного кодекса, где установлено, что дефицит бюджета субъекта РФ не должен превышать $15 \%$ утвержденного общего годового объема доходов бюджета субъекта РФ без учета утвержденного объема безвозмездных поступлений. Превышение допущено только в Республике Хакасия, где дефицит составил около $18 \%$ доходов консолидированного бюджета. Однако сбалансированность бюджетов достигается за счет роста объема государственного долга субъектов РФ, входящих в СФО. За последние четыре года прирост объема государственного долга составил $89 \%$. Государственный долг субъектов РФ СФО на 01.01.2016 г. составил более 334 млрд р., или $15,9 \%$ всего объема государственного долга всех субъектов РФ на эту дату (2,1 трлн р.). 
Исполнение консолидированного бюджета субъектами РФ в 2015 г., тыс. руб.

\begin{tabular}{|l|c|c|c|c|}
\hline \multicolumn{1}{|c|}{ Субъект РФ } & Доходы & Расходы & $\begin{array}{c}\text { Профицит } \\
\text { (дефицит) }\end{array}$ & $\begin{array}{c}\text { Сооношение дефицита } \\
\text { и доходов, \% }\end{array}$ \\
\hline СФО & 1013054028 & 1091560896 & -78506869 & 7,7 \\
Республика Алтай & 16957663 & 17632649 & -674986 & 4,0 \\
Республика Бурятия & 52843528 & 54065796 & -1222268 & 2,3 \\
Республика Тыва & 21158333 & 22369678 & -1211344 & 5,7 \\
Республика Хакасия & 28298909 & 33350390 & -5051482 & 17,9 \\
Алтайский край & 95509079 & 98156823 & -2647743 & 2,8 \\
Забайкальский край & 53187666 & 59772831 & -6585165 & 12,4 \\
Красноярский край & 211416855 & 232528001 & -21111147 & 10,0 \\
Иркутская область & 129088998 & 139024024 & -9935026 & 7,7 \\
Кемеровская область & 132303224 & 141239417 & -8936193 & 6,8 \\
Новосибирская область & 131858329 & 145049851 & -13191522 & 10,0 \\
Омская область & 79029223 & 84184479 & -5155256 & 6,5 \\
Томская область & 61402221 & 64186959 & -2784738 & 4,5 \\
\hline
\end{tabular}

И с точн и к: данные о социально-экономическом положении федеральных округов и регионов Российской Федерации. URL: http://www.gks.ru/bgd/free/B02_83/Main.htm (дата обращения: 07.07.2016).

В табл. 5 представлена динамика государственного долга за 2014-2015 гг. в разрезе субъектов РФ округа, подтверждающая нарастание напряженности в сфере государственных финансов СФО. Объем государственного долга вырос во всех регионах, за исключением Республики Алтай, где сокращение этого показателя достигло $4 \%$. Наибольший темп роста государственного долга - в Иркутской области (79\%). Фиксируется значительная дифференциация объема государственного долга на душу населения по регионам СФО. Если в среднем по округу на душу населения объем государственного долга на 01.01.2016 г. составил 17,3 тыс. р., то в Республике Хакасия этот показатель превысил 31 млн р. (максимальное значение), а в Иркутской области - 8,7 тыс. p. (минимальное значение).

Бюджетным кодексом предусмотрено, что предельный объем государственного долга не должен превышать $100 \%$ доходов региона. Министерство финансов рекомендует не превышать $50 \%$ значения годового дохода бюджета. На рис. 2 представлены данные о соотношении доходов консолидированных бюджетов и объемов государственного долга регионов СФО. Республика Хакасия, Омская область превысили уровень этой рекомендации, Кемеровская область, Красноярский и Забайкальский края близки к такой ситуации.

Структура государственного долга субъектов РФ СФО, по сравнению со структурой государственного долга всех регионов России, в целом менее эффективна. Так, бюджетные кредиты составляют $26 \%$, а в целом по всем субъектам РФ - 37,2 \%; кредиты, полученные субъектами РФ СФО от кредитных организаций, иностранных банков и международных финансовых организаций составляет $44,9 \%$, в целом по всем субъектам РФ - 37,5\%. Государственные гарантии - 0,28 \% объема государственного долга СФО, а в целом по всем регионам страны $-4,9 \%$.

То есть доля «трудных обязательств» при обслуживании государственного долга у регионов СФО больше, чем в среднем по регионам России. 
Таблица 5

Объем государственного долга субъектов РФ СФО на 01.01.2016 г., тыс. руб.

\begin{tabular}{|c|c|c|c|c|c|}
\hline Субъект РФ & $\begin{array}{c}\text { Объем } \\
\text { государст- } \\
\text { венного } \\
\text { долга }\end{array}$ & $\begin{array}{c}\text { Объем } \\
\text { государственного } \\
\text { долга } \\
\text { за прошлый год }\end{array}$ & $\begin{array}{c}\text { Численность } \\
\text { постоянного } \\
\text { населения } \\
\text { на } 01.01 .2015 \text { г., } \\
\text { тыс. чел. }\end{array}$ & $\begin{array}{c}\text { Объем государст- } \\
\text { венного долга } \\
\text { в расчете на душу } \\
\text { населения, тыс. } \\
\text { руб./чел. }\end{array}$ & $\begin{array}{c}\text { Темп } \\
\text { прироста, } \\
\%\end{array}$ \\
\hline СФО & 334813010,77 & 269027615,17 & 19312 & 17.3 & 24 \\
\hline Республика Алтай & 1974511,81 & 2047970,33 & 214 & 9.22 & -4 \\
\hline Республика Бурятия & 10124894,83 & 8495754,43 & 978 & 10.35 & 19 \\
\hline Республика Тыва & 2910382,52 & 2013999,61 & 314 & 9268 & 44 \\
\hline Республика Хакасия & 16676155,83 & 10854385,62 & 536 & 31112 & 53 \\
\hline Алтайский край & 2442541,72 & 2039926,20 & 2385 & 1024 & 19 \\
\hline Забайкальский край & 26459663,16 & 19993264,37 & 1087 & 24,3 & 32 \\
\hline Красноярский край & 84732684,65 & 68739862,95 & 2859 & 29,6 & 23 \\
\hline Иркутская область & 21116630,21 & 11767827,90 & 2415 & 8,7 & 79 \\
\hline Кемеровская область & 58381737,34 & 50814017,68 & 2725 & 21,4 & 14 \\
\hline Новосибирская область & 46728603,13 & 35828093,60 & 2747 & 17,0 & 30 \\
\hline Омская область & 40050032,19 & 36578821,70 & 1978 & 20,3 & 9 \\
\hline Томская область & 23215173,38 & 19853690,78 & 1074 & 21,6 & 17 \\
\hline
\end{tabular}

И с т о ч н и к : сайт Министерства финансов России. URL: http://www.minfin.ru

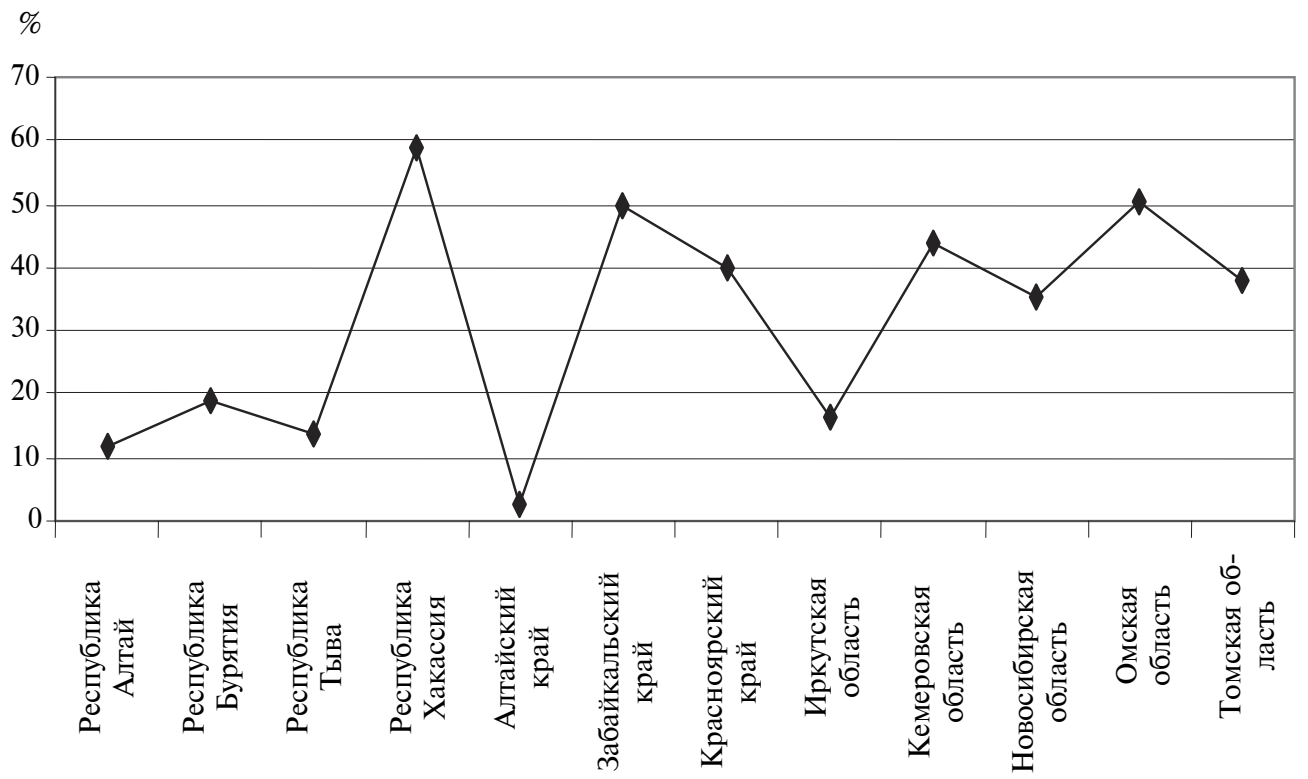

Рис. 2. Соотношение доходов консолидированного бюджета и объема государственного долга субъектов РФ СФО в 2015 г. 


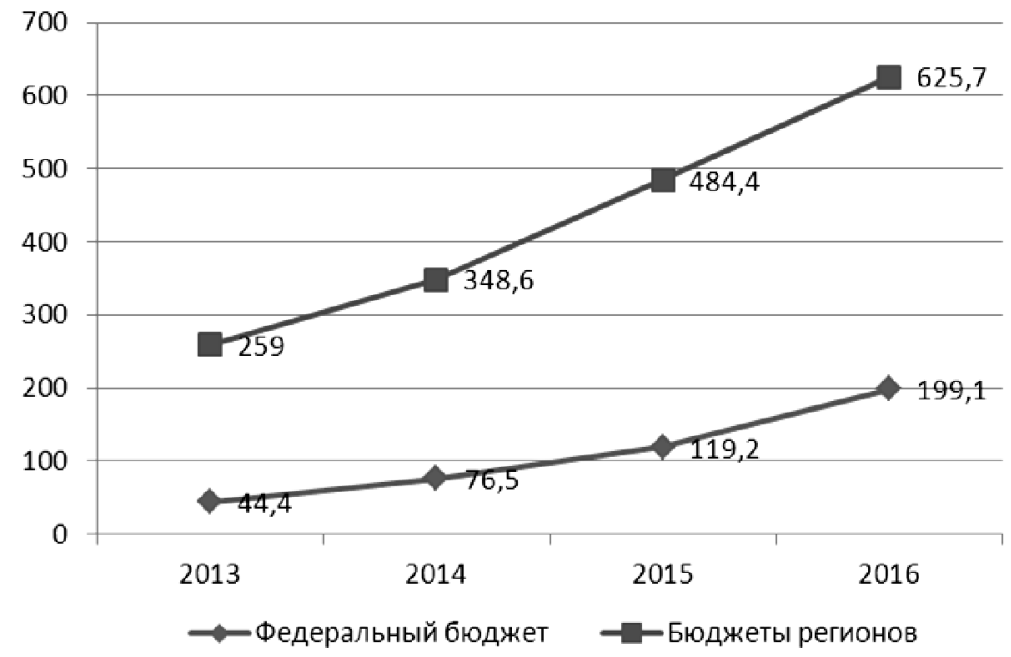

Рис. 3. Планируемое финансирование по строке «Всего» Программы по повышению оплаты труда отдельным категориям работников за счет средств федерального бюджета и консолидированных бюджетов субъектов РФ

Увеличение объема государственного долга субъектов РФ связано с выполнением «Программы поэтапного совершенствования системы оплаты труда в государственных (муниципальных) учреждениях на 2012 2018 годы», утвержденной Распоряжением Правительства РФ от 26.11.2012 г. Программа была принята для исполнения Указа Президента РФ № 597 от 07.05.2012 г. «О мероприятиях по реализации государственной социальной политики». Основной источник финансирования мероприятий Программы консолидированные бюджеты субъектов РФ. На рис. 3 представлены планируемые объемы финансирования.

Меры социальной политики, реализуемые на федеральном уровне, оказали дифференцированное воздействие на макрорегионы. Их эффективность непосредственно определялась состоянием консолидированных бюджетов субъектов РФ. На фоне замедления роста доходов и опережающего роста расходов на заработную плату показатели бюджетов даже сведенные в разрезе макрорегионов ухудшались. Из-за роста расходов, не обеспеченных соответствующим расширением доходной базы, субъекты РФ увеличивали объемы государственных долговых обязательств.

Тенденции конца 2015 г. сохранились в начале 2016 г. Так, объем государственного долга субъектов РФ СФО на 01.04.2016 г. со- ставил 342,8 млрд р. Рост, по сравнению с началом января, $-2,6 \%$.

Представленные данные доказывают, что у регионов СФО нет достаточных бюджетных ресурсов для поддержания потенциала экономического роста.

\section{Выводы}

1. В регионах СФО в 2014-2015 гг. фиксируется падение потребительского спроса, что является серьезным препятствием для восстановления экономического роста. В силу специфики отраслевой специализации регионов округа стратегия поддержания потребительского спроса должна стать центральной для органов управления всех уровней.

2. Негативные тенденции в сфере инвестиций СФО препятствуют восстановлению экономического роста. Если нет инвестиций, не создаются новые рабочие места, нет развития. Это проблема номер один для будущего Сибири.

3. Нужна система мер, обеспечивающая механизмы, при которых поддержка малого предпринимательства становится инструментом региональной политики государства, а региональный аспект - фокусом кардинальных изменений в политике развития малого бизнеса [1]. В текущей ситуации целесообразно поддерживать потенциал экономического роста, увеличивая в приоритетном порядке объемы средств, получаемых региона- 
ми СФО на поддержку малого предпринимательства как через конкурсы Минэкономразвития так и через Фонд развития промышленности, Российскую венчурную компанию, Корпорацию МСП.

4. Стагнация и сокращение экономического роста ведут к сокращению доходов бюджета при сохранении обязательств субъектов РФ, входящих в СФО, в части выполнения социальных расходов. Это приводит к увеличению дефицита и сложностям в реализации стратегии управления государственным долгом, создает трудности при выполнении задач восстановления экономического роста в округе.

5. Для сглаживания возникших диспропорций потребуется передать субъектам РФ СФО дополнительные доходы, содействовать изменению структуры государственного долга или ввести дополнительную дифференциацию в уровне нагрузки для создания условий, при которых снизится уровень дефицита и госдолга консолидированных бюджетов регионов.

6. В условиях активизации потенциала экономического роста целесообразно корректировать долю обязательств, приходящуюся на региональные бюджеты, учитывать факт разбалансированности при резком увеличении дефицита и госдолга, которые имеют место в СФО.

7. Экономические трудности, которые переживает страна, не позволят достичь поставленных целей, если не будут предприняты специальные меры государственного регулирования со стороны федерального центра, способствующие повышению потенциала управления органов власти субъектов РФ, входящих в СФО. Как представляется, для СФО необходимо пересмотреть целевые установки и задачи, поставленные в Стратегии социально-экономического развития Сибири до 2020 года, утвержденной Распоряжением Правительства Российской Федерации № 1120-р от 05.07.2010 г. В Стратегию должны быть включены новые задачи, связанные с проектным подходом ускорения экономического роста, который обеспечит концентрацию финансовых, управленческих, административных ресурсов на решении наиболее важных конкретных задач в экономике и социальной сфере СФО с выходом на ощутимые реальные результаты [16].

Резюмируя вышеизложенное, отметим, что восстановление экономического роста потребует реальной оценки имеющихся ресурсов и учета пространственного разнообразия социально-экономического развития всех макрорегионов и субъектов РФ.

Дальнейшее направление исследований связано с разработкой специальных математических моделей. Предполагается провести эконометрический анализ на основе регрессионных моделей зависимости роста ВРП регионов, входящих в СФО, от рассмотренных факторов, что обеспечит переход от анализа качественных закономерностей к их количественной определенности. Целесообразно при этом использовать модели со стандартизированными бета-весами. Такие модели позволят выяснить, какая из независимых переменных оказывает наибольшее влияние на зависимую переменную, тем самым обосновать очередность мероприятий в программе по восстановлению экономического роста в округе.

Статья подготовлена в рамках Государственного задания Проект XI.173.1.2 (0325-2014-00014) «Региональное и муниципальное управление: диагностика, планирование и мониторинг социально-экономического развития регионов Сибири» № 01201352326.

\section{СПИСОК ЛИТЕРАТУРЫ}

1. Басарева В.Г. Малый бизнес России: теоретические основы исследования, моделирование, концепция государственного регулирования. Новосибирск: ИЭОПП СО РАН, 2013. 295 с.

2. Выступление В.В. Путина на ПМЭФ-2016. URL: https://rg.ru/2016/06/17/reg-szfo/videotransliac iia-vystuplenie-vladimira-putina-na-pmef-2016.html (дата обращения: 24.07.2016).
3. Гранберг А.Г. Основы региональной экономики: учебник для вузов. М.: ГУ-ВШЭ, 2003. 495 с.

4. Гурвич Е. Развитие макроэкономической политики в России: прогресс и проблемы : доклад на XVII Междунар. науч. конф. по проблемам развития экономики и общества. М.: НИУ ВШЭ, 2016.

5. URL: https://conf.hse.ru/data/2016/04/14/11 29618660/\%D0\%9C\%D0\%B0\%D0\%BA\%D1\%80\%D0 
$\% \mathrm{BE} \% \mathrm{D} 1 \% 8 \mathrm{D} \% \mathrm{D} 0 \% \mathrm{BA} \% \mathrm{D} 0 \% \mathrm{BE} \% \mathrm{D} 0 \% \mathrm{BD} \% \mathrm{D} 0 \%$ $\mathrm{BE} \% \mathrm{D} 0 \% \mathrm{BC} \% \mathrm{D} 0 \% \mathrm{~B} 8 \% \mathrm{D} 0 \% \mathrm{BA} \% \mathrm{D} 0 \% \mathrm{~B} 0 . \mathrm{pdf} \quad$ (дата обращения: 20.07.2016).

6. Зубаревич Н.В. В ближайшие пять-семь лет будет социальная деградация. URL: http://so1.ru/news/show/tekst_v_blizhayshie_pyat_sem_let_bud et_socialnaya (дата обращения: 12.06.2016).

7. Ивантер В.В. Стратегия перехода к экономическому росту // Проблемы прогнозирования. 2016. № 1. C. $3-7$.

8. Кулешов В.В. Современные вызовы социально-экономическому развитию России // ЭКО. 2014. № 12. С. 5-14.

9. Малое и среднее предпринимательство в России. М.: Росстат: 2014.

10. Медведев Д. Социально-экономическое развитие России: обретение новой динамики // Вопросы экономики. 2016. № 10. С. 5-30.

11. Минфин предложил сократить финансирование малого и среднего бизнеса // Новая газета. 2016. 29 июля. URL: http://www.novayagazeta.r u/news/1705630.html (дата обращения: 20.08.2016).

12. Об утверждении Стратегии социальноэкономического развития Сибири до 2020 года: Распоряж. Правительства РФ № 1120-p от 05.07.2010 г. URL: http://docs.cntd.ru/document/902 229380 (дата обращения: 07.07.2016).

13. Стратегия развития малого и среднего предпринимательства в России на период до 2030 года: Распоряж. Правительства РФ № 1083-р от 02.06.2016 г. URL: http://rodosnpp.ru/media/rodos/d ocuments/2016/news/rasporiagenie.pdf (дата обращения: 04.07.2016).

14. Региональное и муниципальное управление экономическим развитием в Сибирском федеральном округе / под ред. А.С. Новоселова. Новосибирск: ИЭОПП СО РАН, 2014. 398 с.

15. Социально-экономическое положение Сибирского федерального округа в 2014 году. М.: Федеральная служба государственной статистики, 2015. $84 \mathrm{c}$.

16. Социально-экономическое положение России. Январь-май 2016 г. М.: Росстат, 2016. 400 с.

17. Стенограмма первого заседания Совета по стратегическому развитию и приоритетным проектам. URL: https://rg.ru/2016/06/30/vladimir-putinsozdal-proektnyj-ofis-pri-prezidente.html (дата обращения: 12.06.2016).

18. Басарева В.Г. Влияние малого бизнеса на экономический рост в России // Научно-технические ведомости Санкт-Петербургского государственного политехнического университета. Экономические науки. 2015. № 2(216). С. 46-51. DOI: 10.5862/JE.216.5

19. Keeble D. New Firm and Regional Economic Development: Experience and Impacts is the 1980s // Cambridge Regional Review, 1990, pp. 19-38.

20. Storey D.J. Entrepreneurship and the New Firm. London, UK: Croom Helm, 1982, p. 232.

\section{REFERENCES}

1. Basareva V.G. Malyi biznes Rossii: teoreticheskie osnovy issledovaniia, modelirovanie, kontseptsiia gosudarstvennogo regulirovaniia. Novosibirsk: IEOPP SO RAN, 2013. 295 s. (rus)

2. Vystuplenie V.V. Putina na PMEF-2016. URL: https://rg.ru/2016/06/17/reg-szfo/videotransliaciiavystuplenie-vladimira-putina-na-pmef-2016.html (data obrashcheniia: 24.07.2016). (rus)

3. Granberg A.G. Osnovy regional'noi ekonomiki: uchebnik dlia vuzov. M.: GU-VShE, 2003. 495 s. (rus)

4. Gurvich E. Razvitie makroekonomicheskoi politiki v Rossii: progress i problemy : doklad na KhVII Mezhdunar. nauch. konf. po problemam razvitiia ekonomiki i obshchestva. M.: NIU VShE, 2016. (rus)

5. URL: https://conf.hse.ru/data/2016/04/14/112 9618660/\%D0\%9C\%D0\%B0\%D0\%BA\%D1\%80\%D0\% BE\%D1\%8D\%D0\%BA\%D0\%BE\%D0\%BD\%D0\%BE $\% \mathrm{D} 0 \% \mathrm{BC} \% \mathrm{D} 0 \% \mathrm{~B} 8 \% \mathrm{D} 0 \% \mathrm{BA} \% \mathrm{D} 0 \% \mathrm{~B} 0 . \mathrm{pdf}$ (data obrashcheniia: 20.07.2016). (rus)

6. Zubarevich N.V. V blizhaishie piat'-sem' let budet sotsial'naia degradatsiia. URL: http://so-1.ru/news/ show/ tekst_v_blizhayshie_pyat_sem_let_budet_socialnaya (data obrashcheniia: 12.06.2016). (rus)

7. Ivanter V.V. Strategiia perekhoda k ekonomicheskomu rostu. Problemy prognozirovaniia. 2016. № 1. C. $3-7$. (rus)
8. Kuleshov V.V. Sovremennye vyzovy sotsial'noekonomicheskomu razvitiiu Rossii. EKO. 2014. № 12. S. 5-14. (rus)

9. Maloe i srednee predprinimatel'stvo v Rossii. M.: Rosstat: 2014. (rus)

10. Medvedev D. Sotsial'no-ekonomicheskoe razvitie Rossii: obretenie novoi dinamiki. Voprosy ekonomiki. 2016. № 10. S. 5-30. (rus)

11. Minfin predlozhil sokratit' finansirovanie malogo i srednego biznesa. Novaia gazeta. 2016. 29 iiulia. URL: http://www.novayagazeta.ru/news/1705630. html (data obrashcheniia: 20.08.2016). (rus)

12. Ob utverzhdenii Strategii sotsial'no-ekonomicheskogo razvitiia Sibiri do 2020 goda: Rasporiazh. Pravitel'stva RF № 1120-r ot 05.07.2010 g. URL: http://docs.cntd.ru /document/902229380 (data obrashcheniia: 07.07.2016). (rus)

13. Strategiia razvitiia malogo i srednego predprinimatel'stva v Rossii na period do 2030 goda: Rasporiazh. Pravitel'stva RF № 1083-r ot 02.06.2016 g. URL: http://rodosnpp.ru/media/rodos/documents/20 16/news/rasporiagenie.pdf (data obrashcheniia: 04.07.2016). (rus)

14. Regional'noe i munitsipal'noe upravlenie ekonomicheskim razvitiem v Sibirskom federal'nom okruge. Pod red. A.S. Novoselova. Novosibirsk: IEOPP SO RAN, 2014. 398 s. (rus) 
15. Sotsial'no-ekonomicheskoe polozhenie Sibirskogo federal'nogo okruga v 2014 godu. M.: Federal'naia sluzhba gosudarstvennoi statistiki, 2015. 84 s. (rus)

16. Sotsial'no-ekonomicheskoe polozhenie Rossii. Ianvar'-mai 2016 g. M.: Rosstat, 2016. 400 c. (rus)

17. Stenogramma pervogo zasedaniia Soveta po strategicheskomu razvitiiu i prioritetnym proektam. URL: https://rg.ru/2016/06/30/vladimir-putin-sozdalproektnyj-ofis-pri-prezidente.html (data obrashcheniia: 12.06.2016). (rus)
18. Basareva V.G. The influence of small businesses on the economic growth in Russia. St. Petersburg State Polytechnical University Journal. Economics, 2015, no. 2(216), pp. 46-51. DOI: 10.5862/JE.216.5

19. Keeble D. New Firm and Regional Economic Development: Experience and Impacts is the 1980s. Cambridge Regional Review, 1990, pp. 19-38.

20. Storey D.J. Entrepreneurship and the New Firm. London, UK: Croom Helm, 1982, p. 232.

БАСАРЕВА Вера Гаврииловна - ведущий научный сотрудник Института экономики и организации промышленного производства СО РАН, доктор экономических наук.

630090. пр. Лаврентьева, д. 17, г. Новосибирск, Россия. E-mail: vera.basareva@gmail.com

BASAREVA Vera G. - Institute of Economics and Industrial Engineering.

630090. Acad. Lavrentiev av. 17. Novosibirsk. Russia. E-mail: vera.basareva@gmail.com

Статья поступила в редакцию: 06.10.16 